\title{
The Innovation of Human Resource Investment and Value Relevance in Equity Valuation
}

\author{
Gee Jung Kwon \\ Division of Economics and Commerce, Hanbat National University \\ San 16-1, Duckmyoung-Dong, Yuseong-Gu, Daejeon 305-719, Republic of Korea \\ Tel: 82-42-821-1337Ｅ-mail: geejung@hanmail.net
}

Received: October 23, 2011

Accepted: November 14, $2011 \quad$ Published: December 1, 2011

doi:10.5539/ass.v7n12p22

URL: http://dx.doi.org/10.5539/ass.v7n12p22

This work was supported by Hanbat National University research grant of 2010

\begin{abstract}
This paper explores the innovation and value relevance of human resource investment and market reactions of investors on education and training expense in Korean security markets over the period of 2001-2008. This study tests whether education and training expense is empirically associated with one year after earnings performance and the information content of education and training is immediately reacted in the Korean stock markets. The empirical result of this paper shows consistent results with the hypothesis of this paper. The results document that education and training investment which proxies for human resource investment have innovative value relevance and Korean stock market participants truly recognize the innovative information content of education and training expense.
\end{abstract}

Keywords: Education and training expense, Human resource investment, Value relevance, Firm value, Earnings persistence, Market reaction, Korean security markets

\section{Introduction}

Previous studies on the value relevance of R\&D investment have reported that R\&D activity is significantly related to equity value (Ravenscraft and Scherer, 1982; Cohen and Levin, 1989; Sougiannis, 1994; Lev and Sougiannis, 1996; Lev and Zarowin, 1999; Aboody and Lev, 2001; Lee, 1994; Paek, 1994; Jung, 2002; Cho, 2002; Lee and Kim, 2002; Jeong et al., 2003; Jeong and Cho, 2004; Paek, 2004; Kim; 2004; Ahn and Kwon, 2006; Park et al., 2007) since 1990s. Before 1990s, many literatures have reported competing results about whether R\&D investment has value relevance or not. Because of the dominant evidence that R\&D has positive value relevance after 1990s, many countries have converted the GAAP practice of R\&D investment from expensing to capitalization. After all, R\&D investment has truly recognized as intangible asset creating future potential cash flows by changing GAAP and accounting practice. Like the R\&D investment, many researchers and professionals have believed that the human resource investment can create future potential cash flows even though it is difficult to convince that. Because of this, many researchers have investigated the value relevance of human resource investment. Nevertheless, the empirical result about the value relevance of human resource investment is competing whether it can create future potential cashflows or not.

Human resource is the most important factors in operating firm's facility and creating future benefit, so World Bank suggests human resource should be included in measuring total national value. Training and education investment is representative activity enhancing human resource. But until now, the researches about human resource and its value relevance are not focused than that of R\&D investment. Particularly, Korean economic society has suffered from increasing discharge and temporary employee problem since 1997 economic crisis. So it is recognized as very important problems how promoting human resource ability and whether it can really enhancing the competence of company. If we document that human resource investment has value relevance and it can generate potential future cashflows, this paper will be the foundation of solving human resource problems in Korean society. 
To test this argument, this paper investigates the value relevance of human resource investment by examining whether current year education and training activity is positively associated with next year earnings. In addition, this paper also investigates whether Korean market investors fully react on the innovative value relevance of education and training expense by performing the nonlinear generalized least square regressions. Specifically, this paper divides samples into various subgroups such as big/small\&medium, manufacturing/nonmanufacturing and high technology/low technology firm groups to observe the characteristics of education and training activity and market response to it in listed Korean stock markets over the period from 2001 to 2008.

The study is organized as follows. First section discusses the purpose of this paper. Section 2 reviews previous studies on the value relevance of education and training expense and market response to it. Section 3 designs study hypothesis and empirical models. Section 4 discusses the empirical results. Section 5 summarizes this paper and concludes the study.

\section{Previous Studies on Value Relevance and Market Reaction on Education and Training Expense}

Lucas (1988) discusses that human resource asset includes the intellectual, knowledge, Know-How, and other intangible technical skills of some organization's individuals. Adam Smith (1776) also insist that human resource capability could be acquired by continuous education and training activity for organization members.

Up to the present, many researchers have documented that intangible asset creating future potential cashflows is the mainly created by R\&D activity. But they do not focused on human resource asset directly performing research and development activity.

Some Korean papers, such as Kim (2003) discusses that if education and training activity succeed, it may be accumulated and compose intangible human resource asset. And other researches, such as Bassi and McMurrer, (1998), Kim(2002), Jang and Shin(2002), and Kim and Shin(2003) document that accumulated human resource asset enhance labor productivity, profitability, and firm value.

Many researchers who studies endogenous growth theory also discuss that the creation of human resource asset is made by education and training activity (Arrow, 1962; Uzawa, 1965; Romer, 1986; Lucas, 1988). They insist that companies which create knowledge and technology internally without external technical support and investment can manage to maintain continuous long-term growth. But in accounting and finance academic field, it is hard to test the cause-and-effect relationship between human resource investment and firm value. The reason for that is because it is uncertain whether education and training activity succeed or not (Hall, 1993) and it is also difficult to identify the effect of education and training investment (Lillard and Tan, 1992; Black and Lynch, 1996).

\section{Hypothesis and Empirical Model}

\subsection{Hypothesis}

This study investigates the innovative value relevance of education and training expense proxies for human resource investment by examining whether firms' current year education and training activity are significantly associated with one year after earnings. To do this, this paper designs following hypotheses;

Hypothesis $1(\mathrm{H}-1)$ : Current year education and training expense has positive association with one year after earnings.

This study has two basic assumptions about firms' education and training activity and security market reaction on it. First, education and training expense cannot give any guarantee of future succession. Second, this uncertainty about future succession gives misunderstanding on the education and training investment to security market participants. Because of this misleading, market investors cannot have confidence on future effect of education and training activity. Finally, market investors undervalue the future potential marketing and cash generating power may be made by education and training investment.

The paper also examines whether Korean financial market does expect future potential cash flows may be created by education and training activity. If participants of financial market really recognize the innovative value relevance of education and training investment, they may expect future positive abnormal stock returns by investing their money on firms exerting human resource investment. Therefore, this study assumes that education and training investment may increase firm value by creating future potential cash flows and it also provide abnormal stock returns. To test this, this study designs next hypothesis;

Hypothesis 1 (H-2): Korean financial market truly recognizes the innovative value relevance of education and training expense. 


\subsection{Empirical Model for Hypotheses}

This paper designs empirical model on the basis of efficient market theory. Efficient market theory says all information can affect firm value is efficiently and immediately reflected on the stock price, that one cannot take additional returns in excess of average market returns. This paper assumes that information of education and training expense proxies for human resource investment is positively associated with future abnormal returns. To test this assumption, this study adopts Mishkin (1983) and Sloan (1996)'s empirical model and then this study changes their model as followings to examine whether education and training expense is significantly associated with future incremental firm value.

$$
\begin{aligned}
& E_{+1}=\gamma_{0}+\gamma_{1}+E B E R_{\xi}+\gamma_{2} E R_{\xi}+\varepsilon_{t+1} \\
& A R_{\xi+1}=\alpha_{0}+\beta_{1}\left(E+1+\gamma_{10}-\gamma_{1} E E B R_{\xi}-\gamma_{2} E R\right)+\varepsilon_{\xi+1}
\end{aligned}
$$

Where, $\mathrm{E}_{\mathrm{t}+1}$ (one year after earnings) is defined as operating income deflated by total assets of the year $\mathrm{t}+1$. $E_{B H R}$ is current year operating income before deducting total education and training expense of year $t, H_{t}$ is total education and training expense in period $t$ deflated by total assets of year $t$, and $\mathrm{AR}_{t+1}$ is abnormal stock returns of year $\mathrm{t}+1$. This study calculates total education and training expense as following equation (a).

$$
B R_{t}=I B H R_{\tau}+W A U E R_{\tau}
$$

Where, $\mathrm{HR}_{\mathrm{t}}$ : total education and training expense in period $\mathrm{t}$,

$\mathrm{ISHR}_{\mathrm{t}}$ : education and training expense reported on income statement in period $t$,

MAUHR $\mathrm{t}$ : education and training cost reported on statement of the costs of goods manufactured in period t,

$\gamma_{1}$ and $\gamma_{2}$ are coefficients of earnings before deducting total education and training expense respectively. Equation (1) is for the test of the value relevance of education and training expense by estimating $\gamma_{2}$. If financial market investors truly predict the innovative value relevance of education and training expense $\left(\tau_{2}=\tau_{2}^{*}\right)$, it shows the evidence that misreaction of financial market participants on education and training expense does not exist. This can give us the confidence of this paper's assumption that market efficiency about human resource investment really exist in Korean stock market. This paper investigates this assumption for education and training expense by testing equation (2).

\section{Empirical Results}

\subsection{Sample Selection and Data Source}

This study employs all empirical sample data from the KIS-VALUE (Korea Investors Service-Financial Analysis System) database. The empirical data covers the 8-year period of 2001-2008 in listed Korean stock market (Korea Exchange: KRX). In doing sample selection, this paper includes firms with earnings and education and training expense data for empirical test, and excludes financial banking, insurance, public business firms and impairment of capital firms on the KIS-VALUE database. Before doing empirical test, the study excludes outliers with Cook's Distance greater than 0.5 and absolute value of student residuals greater than 2. <Table 1> shows sample data selection process over the period of 2001-2008.

$<$ Insert Table 1 Here $>$

\subsection{Empirical Results}

\subsubsection{Descriptive Statistics}

$<$ Table 2> shows descriptive statistics for firm-year sample data of this study. This paper includes 4,523 firm-year samples for the period from 2001 to 2008. Means of $\mathrm{AR}_{\mathrm{t}+1}$ is 0.08591 , and minimum and maximum values are -1.61806 and 50.72883 respectively. Means of $E_{t+1}$ is 0.03760 ; its minimum value is -2.08315 . Means of $E B H R_{t}$ is 0.03254 ; its maximum value is 28.52650 . Total Means of $\mathrm{HR}_{\mathrm{t}}$ is 0.00396 ; its standard deviation is 0.02954 .

$<$ Insert Table 2 Here $>$ 


\subsubsection{Correlation Analysis}

$<$ Table $3>$ provides the result of pearson correlation analysis between main variables used in this study. AR, E, and EBHR are not significantly correlated, while E and EBHR are negatively correlated at the $1 \%$ level of significance. And the correlation between HR and EBHR shows the same result with E and EBHR.

$<$ Insert Table 3 Here $>$

\subsubsection{The innovative value relevance of human resource investment}

This study performs regressions to examine the innovative value relevance of education and training expense proxies for human resource investment in listed Korean security markets. This paper provides regression results on the innovative value relevance of education and training expenses over the period of $2001-2008$. This paper carries out multiple regressions for all samples split into several subgroups such as big/small\&medium, manufacturing/nonmanufacturing, and high technology/low technology sample groups to observe characteristics of education and training expense in listed Korean stock markets.

This study also carries out the nonlinear generalized least square regressions with total and subgroup samples to examine market participant's reaction on the value relevance information of education and training expense. This paper also divides entire samples into big/small\&medium, manufacturing/nonmanufacturing, and high technology/low technology sample firm groups to test the change of market response to the information of human resource investment in listed Korean security markets.

\subsubsection{The value relevance and market reaction on education and training expense: Entire firm}

$<$ Table $4>$ presents the value relevance of education and training investment in entire sample firm group. The result shows that negatively significant relationship between current year education and training expense and one year after earnings at the $5 \%$ level of significance. This result shows that education and training expense has negative value relevance in total sample data.

This study performs nonlinear generalized least square regression of next year abnormal returns on current year

education and training expense in entire sample groups. $<$ Table $4>$ presents that the coefficients of $\gamma_{1}$ is

0.026368 and the coefficients of $\gamma_{1}^{*}$ is -0.0044 in total sample group. The likelihood ratio statistics $\left(\gamma_{1}=\gamma_{1}^{*}\right)$ in nonlinear generalized least square regression does not show any significance.

$<$ Table $4>$ also shows the coefficients of $\gamma_{2}$ is -0.09019 and the coefficients of $\gamma_{2}^{\mathrm{x}}$ is 0.119203 in total sample

group. The likelihood ratio statistics $\left(\gamma_{2}=\gamma_{2}^{\text {si }}\right)$ does not show any significance in nonlinear generalized least square regressions.

This result suggests that Korean stock market investors truly expect the negative value relevance of education and training expense for security prices. This result also indicates that investors truly estimate the value relevance of education and training expense in listed Korean stock markets.

$<$ Insert Table 4 Here $>$

4.2.3.2 The innovative value relevance and market reaction of education and training expense: Big firm group vs. Small\&Medium firm group

$<$ Table $5>$ shows the value relevance and market reaction of education and training expense in Big/Small \& Medium firm groups. Big firm group is defined as firms with more than 1 thousand employees or assets amount of 500 billion won (USD 600,000,000) and Small\&Medium firm group is defined as firms not included in Big firm group.

The result of $<$ Table $5>$ show current year education and training expense has positively significant relationship with next year earnings at the $5 \%$ level of significance only in Big firm sample group. Moreover, the adjusted $\mathrm{R}^{2}$ of Big firm group (0.2245) is greater than that of the Small\&Medium firm group (-0.000). The result indicates that positive relationship between current year education and training expense and next year earnings exist only in Big firm sample group. 
This paper also performs nonlinear generalized least square regression of next year abnormal returns on current year earnings and education and training activity both in Big and Small \& Medium firm groups. <Table 5> presents the coefficients of $\gamma_{1}$ are 0.264421 and 0.007274 , the coefficients of $\gamma_{1}^{*}$ are 0.008882 and -0.041629 in Big firm and Small \& Medium groups respectively. The likelihood ratio statistics $\left(\gamma_{1}=\gamma_{1}^{*}\right)$ in the nonlinear generalized least square regression is significant at the $1 \%$ level only in Big firm sample group.

$<$ Table 5> also presents the coefficients of $\gamma_{2}$ are 0.098972 and -0.06229 , the coefficients of $\gamma_{2}^{\star}$ are 0.0004577 and 0.207287 in Big/Small\&Medium sample groups respectively. The likelihood ratio statistics $\left(\gamma_{2}=\gamma_{2}^{*}\right)$ in the nonlinear generalized least square regressions shows no significance both in Big/Small\&Medium firm sample groups.

This result shows market investors both on Big firm and Small \& Medium firm groups truly estimate the value relevance of education and training expense for security prices. The result also indicates that investors on Big firm groups truly estimate the positive value relevance of education and training expense and investors on Small\&Medium firm group fully expect the negative value relevance of education and training investment in Korean security markets.

$<$ Insert Table 5 Here $>$

$<$ Table $6>$ presents the value relevance market response to education and training expense in manufacturing and nonmanufacturing firm groups. A manufacturing firm group is defined as firms involved in manufacturing industries of Korean Investors Service (KIS) industry middle level classification, and nonmanufacturing firm sample is defined as firms not involved in manufacturing firm of Korean Investors Service (KIS) industry middle level classification.

The empirical result indicates that current year education and training expense is negatively related to next year earnings both in manufacturing and nonmanufacturing firm groups; the coefficient of HR (-0.10492) of manufacturing firm group shows significant ( $5 \%$ level) estimates, while that of nonmanufacturing firm group does not (-0.06648).

This paper also carries out nonlinear generalized least square regression of next year after abnormal returns on current year education and training expense both in manufacturing and nonmanufacturing firm groups. $<$ Table

6> shows that the coefficients of $\gamma_{1}$ are 0.005607 and 0.23748 , the coefficients of $\gamma_{1}^{*}$, are 0.01508 and -0.00631 in manufacturing and nonmanufacturing firm groups respectively. The likelihood ratio statistics $\left(\gamma_{1}=\gamma_{1}^{*}\right)$ in the nonlinear generalized least square regression is significant at the $1 \%$ level only in nonmanufacturing sample group.

<Table 6> also shows the coefficients of $\gamma_{2}$ are -0.10492 and -0.06648 , the coefficients of $\gamma_{2}^{*}$ are 0.111622 and 0.034736 in manufacturing and nonmanufacturing firm groups respectively. The likelihood ratio statistics $\left(\gamma_{2}=Y_{2}^{*}\right)$ in nonlinear generalized least square regressions does not show any significance both in manufacturing and nonmanufacturing firm groups.

This result shows Korean stock market investors both on manufacturing and nonmanufacturing firm groups truly predict the negative value relevance of education and training expense for stock prices. This result also indicates 
that investors both on manufacturing and nonmanufacturing firm groups truly react on the information of education and training expense.

$<$ Insert Table 6 Here $>$

$<$ Table $7>$ shows the empirical results of market response to education and training expense in high technology and low technology firm groups. High and low technology firm groups are classified in accordance with Himmelberg and Petersen (1994) classification. Himmelberg and Petersen (1994) involves chemicals, pharmaceuticals, metal, electronic components, medical, precision and optical instruments, electrical equipment in high technology industry and others included in low technology industry

The empirical result shows current year education and training expense is negatively related to next year earnings only in high technology firm group; the coefficient of HR (-0.10482) of high technology firm group shows significantly negative estimates, while that of low technology firm group (0.03396) presents does not show any significance.

$<$ Table $7>$ shows significantly negative relationship between current year education and training expense and next year earnings exists in high technology firm group, while no significant relationship exists in low technology firm group. This paper also performs nonlinear generalized least square regression of next year abnormal stock returns on current year education and training activity both in high technology and low technology firm groups. $<$ Table $7>$ shows the coefficients of $\gamma_{1}$ are -0.01565 and 0.272762 , the coefficients of $\gamma_{1}^{*}$ are -0.05178 and 0.069836 in high technology and low technology firm groups respectively. The likelihood ratio statistics $\left(\gamma_{1}=\gamma_{1}^{*}\right)$ in nonlinear generalized least square regression does not show any significance.

$<$ Table $7>$ also presents the coefficients of $\gamma_{2}$ are -0.10481 and 0.033958 , the coefficients of $\gamma_{2}^{*}$ are 0.430193 and -5.39625 in high technology and low technology firm groups respectively. The likelihood ratio statistics $\left(\gamma_{2}=\gamma_{2}^{*}\right)$ in the nonlinear generalized least square regressions presents significance at the $10 \%$ level in high technology firm group and 5\% level in low technology firm group respectively.

This empirical result indicates that Korean stock market investors on low technology firm group do not fully expect the value relevance of education and training activity for stock prices. This result also suggests that Korean security market investors on low technology firm group underestimate the value relevance of education and training activity.

\section{$<$ Insert Table 7 Here $>$}

This paper performs multiple regressions by dividing all data into two groups of equal numbers according to the magnitude of education and training expense. This serves as a test of value relevance of education and training activity according to the size of investment in listed Korean stock markets. $<$ Table $8>$ shows the empirical results of the value relevance and market reaction on education and training expense by splitting total samples into high education and training expense and low education and training expense firm groups.

The empirical result shows current year education and training expense is positively related to next year earnings at $5 \%$ level of significance $(0.11912)$ in high education and training expense firm group, while it is negatively related to next year earnings at $1 \%$ level of significance (-72.82029) in low education and training expense firm group. The result indicates that the positive relationship between one year after earnings and current year education and training expense exists in high education and training activity firm group, while negative relationship exists in low education and training activity firm group

This study also carries out nonlinear generalized least square regression of next year abnormal stock returns on current year education and training activity both in high technology and low technology firm groups. $<$ Table $8>$ 
displays the coefficients of $\gamma_{1}$ are 0.195742 and 0.000956 , the coefficients of $\gamma_{1}^{*}$ are -0.09378 and -0.23534 in high education and training expense and low education and training expense firm groups respectively. The likelihood ratio statistics $\left(\gamma_{1}=\gamma_{1}^{*}\right)$ in nonlinear generalized least square regression shows $5 \%$ level of significance only in low education and training expense firm group.

$<$ Table $8>$ also displays the coefficients of $\gamma_{2}$ are 0.118863 and -72.8032 , the coefficients of $\gamma_{2}^{*}$ are 0.141524 and -222.341 in high education and training expense and low education and training expense firm groups respectively. The likelihood ratio statistics $\left(\gamma_{2}={ }^{\gamma}\right)$ in the nonlinear generalized least square regressions does no shows any significance both in high education and training expense and low education and training expense firm groups respectively.

This empirical result suggests that Korean stock market participants fully predict the value relevance of education and training activity for security prices. Specifically The result also indicates that Korean stock market investors on high education and training expense firm group fully estimate the positive value relevance of education and training activity, and investors on low education and training expense firm group fully estimate the negative value relevance of education and training activity

$<$ Insert Table 8 Here $>$

This paper performs multiple regressions by splitting total sample data into four groups of equal numbers according to the magnitude of education and training expense. This can provide us the precise test of value relevance of education and training activity according to the magnitude of investment in listed Korean security markets. $<$ Table $9>$ displays the value relevance and market response to education and training expense by splitting total samples into 4 quantile sample groups according to the magnitude of education and training investment $.1^{\text {st }}$ quantile group involves firms with the first big education and training expense, and $4^{\text {th }}$ quantile group is includes firms with the least education and training expense group.

The empirical result shows current year education and training expense is positively related to next year earnings at $5 \%$ level of significance $(0.12394)$ in the $1^{\text {st }}$ quantile sample group, while they are negatively related to one year after earnings at $5 \%(-122.35146)$ and $1 \%(-521.98487)$ level of significance in the $3^{\text {rd }}$ and the $4^{\text {th }}$ sample group respectively. In addition, the $2^{\text {nd }}$ quantile sample group does not show significant statistics.

The result suggests that the positive relationship between one year after earnings and current year education and training expense exists only in the $1^{\text {st }}$ quantile sample group, while negative relationship exists in the $3^{\text {rd }}$ and $4^{\text {th }}$ sample group. This indicates that the value relevance of education and training expense is the more positive, the bigger firms have, while the more negative, the less firms have.

This paper also performs nonlinear generalized least square regression of one year after abnormal returns on current year education and training activity in all quantile groups. $<$ Table $9>$ shows the likelihood ratio statistics $\left(\gamma_{2}=\gamma_{2}^{*}\right)$ in the nonlinear generalized least square regressions does no shows any significance in all quantile groups respectively. This result suggests that Korean stock market participants truly expect the value relevance of education and training activity for stock prices in all quantile groups.

$<$ Insert Table 9 Here $>$

\section{Conclusions}

This study investigates the innovative value relevance of education and training expense and security market reactions over the period from 2001 to 2008 . This paper examines the value relevance of education and training activity by testing whether current year education and training expense is significantly related to next year earnings. This study also investigates market response to education and training expense by performing nonlinear generalized least square regression of next year abnormal returns on current year education and 
training activity. These empirical test results give us the evidence that the reaction degree of Korean stock market on education and training activity.

To do this, this paper tests hypothesis 1 (Current year education and training expense has positive association with one year after earnings) and hypothesis 2 (Korean financial market truly recognizes the innovative value relevance of education and training expense). For precise examination, this paper divides all samples into several subgroups such as, big/small\&medium, manufacturing/nonmanufacturing and high technology/low technology to observe the characteristics of the value relevance of education and training expense and market reactions in listed Korean stock market.

Contrary to hypothesis of this paper, the empirical results of this paper show that current year education and training expense is negatively related to next year earnings. This suggests that education and training expenses have negative value relevance in listed Korean stock markets.

However, the empirical results significantly support the second hypothesis of the paper. The results of this study show that Korean financial market investors truly react on the value relevance of education and training activity in total firm group and all subgroups except low technology firm group. This suggests that the Korean financial market participants truly estimate the information content of education and training activity.

The evidence of this study has important implications in finance literature investigating the value relevance of education and training expense and market response to it. This study also suggests that the response of Korean financial market investors to the education and training expense activity are immediately reflected on financial market.

The empirical results of this study are contrary to prior empirical results. Many previous literatures report that education and training activity has positive association with accounting performance proxies for firm value. But this paper provide the opposite evidence that education and training activity has no positive influence on firm value at least in listed Korean stock market. Moreover, Korean stock market participant fully react on the information content of education and training activity. But, this paper has important limitation in investigating the value relevance and market reaction of education and training expense. This paper does not include international data except Korea. This condition gives us the limitation in interpreting the empirical result of this paper, so the implication should be restricted to listed Korean stock market.

\section{References}

Aboody, D. and B. Lev. (2001). R\&D Productivity in the chemical industry. Working paper, New York University.

Ahn, H. B., and G. J. Kwon. (2006). An Analysis on Firm's Value based the Innovation of R\&D. Korean Accounting Review, 31(3): 27-61 [Printed in Korean].

Bassi, L. \& McMurrer, D. P. (1998). Training Investments can Mean Financial Performance. Training and Development, (May), 40-43.

Black, S. and Lynch, I. (1996). Human-Capital Investments and Productivity. American Economic Review, 86(2), 263-267.

Chung, H. Y., and S. I. Cho. (2004). Value-Relevance of Accounting Information on Intangibles. Korean Accounting Review, 29(3): 1-31 [Printed in Korean].

Cohen, W. and R. Levin. (1989). Empirical studies of innovation and market structure, in: R. Schmalensee and R. Willig, eds., Handbook of industrial organization, Vol. II . Elsevier Science B.V., Amsterdam.

Dae Lak Lee and Myoung Hwan, Kim. (2002). A study on the Influence of R\&D Expenditure on Film`s Growth Rate - Focusing on KOSDAQ market. Journal of Taxation and Accounting, Vol. 3(1), 5-31. [Printed in Korean].

H. Uzawa. (1965). Optimum technological change in an aggregative model of economic growth. International Economic Review, 6, 18-31. http://dx.doi.org/10.2307/2525621

Hall, B. H. (1993). The Stock Market Valuation of R\&D Investment during the 1980s. American Economic Review, 83: 259-64.

Hay Y. Chung, Sung Il Jeon and Hyon Joong, Kim. (2003). Different Value Relevance of R\&D Accounting Information Among Industries. Korean Management Review, Vol. 32(1), 257-282. [Printed in Korean].

Himmelberg, C. P., and B. C. Petersen. (1994). R\&D and internal finance: a panel study of small firms in high-tech industries. Review of Economics and Statistics, 76, 1994: 38-51. http://dx.doi.org/10.2307/2109824 
Jae Won Jeong. (2002). An Investigation of the Effects of R\&D Expenditure on Equity Value in Korea Securities Dealers Automated Quotation. Review of Business and Economics, Vol. 15, 1-21. [Printed in Korean].

Jee Ihn, Jang and Sang Chul, Shin. (2002). The Value-Relevance of Labor-Related Costs in Stock Valuation. Journal of Korean Academic Business Administration, Vol. 32, 431-451 [Printed in Korean].

Jin-Yeong Kim. (2004). Human Cpaital and Economic Growth: An Empirical Investigation on Endogenous Growth Theory. Journal of Korea Trade, Vol. 2(5), 103-127. [Printed in Korean].

K.J. Arrow. (1962). The economic implications of learning by doing. Review of Economic Studies, 29, 155-173. http://dx.doi.org/10.2307/2295952

Kim, Ahn Kook. (2002). The Analysis of Productivity Effects of In-Frim Education and Training in Korea. The Korean Economics Review, 50(3), 341-367. [Printed in Korean].

Kim, Yeon Yong and Gun Gon, Shin. (2003). The Effects of Education \& Training Costs on Enterprise Value. The Korean Management Consulting Review, Vol. 3, 67-84. [Printed in Korean].

Lev, B and T. Sougiannis. (1996). The Capitalization, Amortization and Value Relevance of R\&D. Journal of Accounting and Economics, 21, pp. 107-138. http://dx.doi.org/10.1016/0165-4101(95)00410-6

Lev, B. and P. Zarowin. (1999). The Boundaries of Financial Reporting and How to Extend Them. Journal of Accounting Research, (Autumn), pp. 353-385. http://dx.doi.org/10.2307/2491413

Lillard, L. A. and Tan, H. W. (1986). Private Sector Training. Santa Monica, Cal.: Rand Corporation.

Lucas, R. E. (1988). On the Mechanics of Economic Development. Journal of Monetary Economics, 22, 3-42. http://dx.doi.org/10.1016/0304-3932(88)90168-7

Mishkin, F. (1983). A Rational Expectations Approach to Macro econometrics: Testing Policy Effectiveness and Efficient Markets Models. Chicago, IL: University of Chicago Press.

Myung Jang, Baek. (1994). The Effect of R\&D Expense on Earnings, Revenues and Stock Prices. Yeonsei University Doctoral Dissertation [Printed in Korean].

Paek, Wonsun. (2004). The Effect of the Association Between R\&D Expenses and Abnormal Earnins on Equity Valuation. Korean Accounting Review, 29(4): 1-32 [Printed in Korean].

Ravenscraft, D. and Scherer, F. M. (1982). The lag Structure of Returns to Research and Development. Taylor and Francis Journals, 14(6): 603-620.

Romer, P.M. (1986). Increasing returns and long-run growth. Journal of Political Economy, 94, 1002-1037. http://dx.doi.org/10.1086/261420

Sang Man, Lee. (1994). An Empirical Study on Predictability of R\&D Expense and Advertising Expenditure. Dankook University Doctoral Dissertation [Printed in Korean].

Sloan, R.G. (1996). Do Stock Prices Fully Reflect Information in Accruals and Cash Flows about Future Earnings? The Accounting Review, Vol. 71(July), pp. 289-316.

Smith, Adam. (1776). An Inquiry into the Nature and Causes of the Wealth of Nations. London: Methuen and Co., Ltd.

Sougiannis, T. (1994). The accounting valuation of corporate R\&D. The Accounting Review, 69: 44-68.

Sung Pyo, Cho. (2002). Development of Korean R\&D Scoreboard. Ministry of Science and Technologh. [Printed in Korean].

Won Park, Sang-Kyu, Park and Chan-Soo Lee. (2007). The Relation between Intangible Resources and Sustainability of Competitive Advantage. Korean Industrial Economic Review, Vol. 20(6), 2265-2286. [Printed in Korean].

Woo-Sik Kim. (2004). A Study on Relationship between R\&D Activities and Corporate Performance in Korean Electronics Corporations. Korean Industrial Economic Review, 17, 1467-1484. [Printed in Korean]. 
Table 1. Selection of sample firms

\begin{tabular}{|l|c|}
\hline Sum of Listed companies at the end of 2001-2008(firm-year) & 5,880 \\
\hline Minus (-): & $(1,357)$ \\
(1) Firms that do not settle their accounts in December & \\
(2) Financial banking businesses & \\
(3) Issues in administration & \\
(4) capital encroachment firms & \\
\hline Total sample firms(firm-year) & 4,523 \\
\hline
\end{tabular}

Table 2. Descriptive Statistics

\begin{tabular}{|c|c|c|c|c|c|c|}
\hline Year & Number & Variables & Mean & Standard deviation & Min & Max \\
\hline \multirow{3}{*}{$2001-2008$} & \multirow{3}{*}{4,523} & $\mathrm{AR}_{\mathrm{t}+1}$ & 0.08591 & 1.02507 & -1.61806 & 50.72883 \\
\cline { 3 - 7 } & & $\mathrm{E}_{\mathrm{t}+1}$ & 0.03760 & 0.48210 & -2.08315 & 28.53117 \\
\cline { 3 - 7 } & & $\mathrm{EBAD}_{\mathrm{t}}$ & 0.03254 & 0.48922 & -2.41312 & 28.52650 \\
\cline { 3 - 7 } & & $\mathrm{AD}_{\mathrm{t}}$ & 0.00396 & 0.02954 & 0 & 0.85463 \\
\hline
\end{tabular}

Variable definitions: $\mathrm{AR}_{\mathrm{t}+1}=$ Abnormal stock returns at the end of fiscal year $\mathrm{t}+1$, where year $\mathrm{t}+1$ is the event year; $\mathrm{E}_{\mathrm{t}+1}=$ Accounting earnings in period $\mathrm{t}+1$ deflated by total assets of year $\mathrm{t}+1 ; \mathrm{EBAD}_{\mathrm{t}}=$ Accounting earnings before deducting total education and training expense in period $t$ deflated by total assets of year $t ; \mathrm{AD}_{\mathrm{t}}=$ Total education and training expense in period $t$ deflated by total assets of year $t$.

Table 3. Pearson Correlations

\begin{tabular}{|c|c|c|c|c|}
\hline Variables & $\mathrm{AR}$ & $\mathrm{E}$ & $\mathrm{EBAD}$ & $\mathrm{AD}$ \\
\hline \multirow{2}{*}{$\mathrm{AR}$} & \multirow{2}{*}{1.00000} & & & \\
& & & & \\
\hline \multirow{2}{*}{$\mathrm{E}$} & -0.00280 & \multirow{2}{*}{1.00000} & & \\
\cline { 3 - 4 } $\mathrm{EBAD}$ & $(0.8505)$ & & & \\
\hline & 0.00388 & -0.06338 & \multirow{2}{*}{1.00000} & \\
\cline { 2 - 4 } & $(0.7943)$ & $(<.0001)$ & & \\
\hline \multirow{2}{*}{$\mathrm{AD}$} & -0.00804 & -0.00602 & -0.07013 & \multirow{2}{*}{1.00000} \\
\cline { 2 - 4 } & $(0.5887)$ & $(0.6856)$ & $(<.0001)$ & \\
\hline
\end{tabular}

1) Pearson's coefficient of correlation, two-sided test, Variable definitions: Refer to $<$ Table $2>$

2) $*$ p $<0.1, * *$ p $<0.05, * * * p<0.01$ 
Table 4. Market Response of Education and Training Expense: Total Firm

\begin{tabular}{|c|c|c|c|c|c|c|c|}
\hline \multicolumn{8}{|c|}{ (A) Equation: $E_{4+1}=\gamma_{0}+\gamma_{1}+E E E R_{4}+\gamma_{2} E R_{4}+c_{4+1}$} \\
\hline Number & \multicolumn{3}{|c|}{ Variables } & Coefficients & t value & $\operatorname{Adj} R^{2}$ & F-value \\
\hline \multirow{3}{*}{4,523} & \multicolumn{3}{|c|}{$\operatorname{Intercept}\left(\gamma_{0}\right)$} & 0.03453 & $27.94 * *$ & \multirow{3}{*}{0.0070} & \multirow{3}{*}{16.75} \\
\hline & \multicolumn{3}{|c|}{$\operatorname{EBHR}_{t}\left(\gamma_{1}\right)$} & 0.02637 & $4.96 * *$ & & \\
\hline & \multicolumn{3}{|c|}{$\operatorname{HR}_{t}\left(\gamma_{2}\right)$} & -0.09019 & $-2.19 *$ & & \\
\hline \multicolumn{8}{|c|}{ 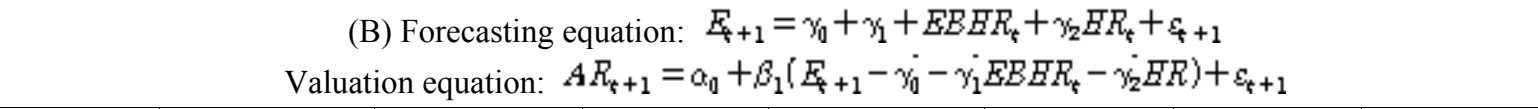 } \\
\hline Number & $\gamma_{1}$ & $\gamma^{*}$ & $\gamma_{2}$ & $\gamma^{*}$ & $\begin{array}{c}\text { Test of } \\
\text { market } \\
\text { efficiency }\end{array}$ & $\begin{array}{l}\text { Likelihood } \\
\text { ratio } \\
\text { statistic }\end{array}$ & $\begin{array}{c}\text { Marginal } \\
\text { significance } \\
\text { level }\end{array}$ \\
\hline \multirow{2}{*}{4,523} & \multirow{2}{*}{$0.026368 * *$} & \multirow{2}{*}{-0.0044} & \multirow{2}{*}{$-0.09019^{*}$} & \multirow{2}{*}{0.119203} & $\gamma_{1}=\gamma^{*}{ }_{1}$ & 0.29 & 0.5930 \\
\hline & & & & & $\gamma_{2}=\gamma_{2}^{*}$ & 0.22 & 0.6381 \\
\hline
\end{tabular}

Variable definitions: Refer to <Table 2>,* (**): Significant at the $.05(.01)$ level.

Table 5. Market Response of Education and Training Expense: Big vs. Small \& Medium

\begin{tabular}{|c|c|c|c|c|c|c|c|c|}
\hline \multicolumn{9}{|c|}{ (A) Equation: $E_{4+1}=\gamma_{1}+\gamma_{1}+E B E R_{4}+\gamma_{2} E R_{r}+r_{4}+1$} \\
\hline Group & Number & \multicolumn{3}{|c|}{ Variables } & Coefficients & t value & $\operatorname{Adj} R^{2}$ & F-value \\
\hline \multirow{3}{*}{ Big } & \multirow{3}{*}{2,833} & \multicolumn{3}{|c|}{$\operatorname{Intercept}\left(\gamma_{0}\right)$} & 0.03381 & $43.10 * *$ & \multirow{3}{*}{0.2245} & \multirow{3}{*}{359.11} \\
\hline & & \multicolumn{3}{|c|}{$\operatorname{EBHR}_{t}\left(\gamma_{1}\right)$} & 0.26442 & $26.48 * *$ & & \\
\hline & & \multicolumn{3}{|c|}{$\operatorname{HR}_{t}\left(\gamma_{2}\right)$} & 0.09897 & $2.01 *$ & & \\
\hline \multirow{3}{*}{$\begin{array}{l}\text { Small \& } \\
\text { Medium }\end{array}$} & \multirow{3}{*}{1,690} & \multicolumn{3}{|c|}{$\operatorname{Intercept}\left(\gamma_{0}\right)$} & 0.01628 & $5.24 * *$ & \multirow{3}{*}{-0.000} & \multirow{3}{*}{0.92} \\
\hline & & \multicolumn{3}{|c|}{$\operatorname{EBHR}_{t}\left(\gamma_{1}\right)$} & 0.00727 & 0.86 & & \\
\hline & & \multicolumn{3}{|c|}{$\operatorname{HR}_{t}\left(\gamma_{2}\right)$} & -0.06230 & -0.92 & & \\
\hline \multicolumn{9}{|c|}{ 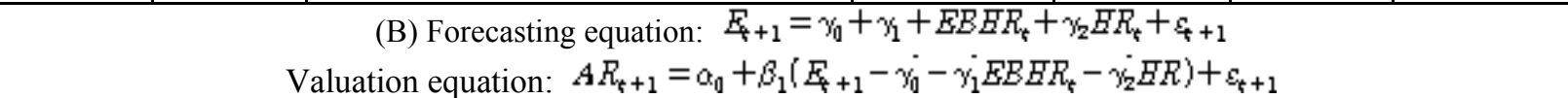 } \\
\hline Group & Number & $\gamma_{1}$ & $\gamma^{*}{ }_{1}$ & $\gamma_{2}$ & $\gamma^{*}{ }_{2}$ & $\begin{array}{l}\text { Test of } \\
\text { market } \\
\text { efficiency }\end{array}$ & $\begin{array}{c}\text { Likelihood } \\
\text { ratio } \\
\text { statistic }\end{array}$ & $\begin{array}{c}\text { Marginal } \\
\text { significance } \\
\text { level }\end{array}$ \\
\hline \multirow{2}{*}{ Big } & \multirow{2}{*}{2,833} & \multirow{2}{*}{$0.264421 * *$} & \multirow{2}{*}{0.008882} & \multirow{2}{*}{$0.098972 *$} & \multirow{2}{*}{0.004577} & $\gamma_{1}=\gamma^{*}{ }_{1}$ & 8.42 & 0.0037 \\
\hline & & & & & & $\gamma_{2}=\gamma^{*}{ }_{2}$ & 0.05 & 0.8279 \\
\hline \multirow{2}{*}{$\begin{array}{l}\text { Small \& } \\
\text { Medium }\end{array}$} & \multirow{2}{*}{1,690} & \multirow{2}{*}{0.007274} & \multirow{2}{*}{0.041629} & \multirow{2}{*}{-0.06229} & \multirow{2}{*}{0.207287} & $\gamma_{1}=\gamma^{*}{ }_{1}$ & 0.02 & 0.8820 \\
\hline & & & & & & $\gamma_{2}=\gamma^{*}{ }_{2}$ & 0.02 & 0.8851 \\
\hline
\end{tabular}

Variable definitions: Refer to <Table 2>,* (**): Significant at the $.05(.01)$ level. 
Table 6. Market Response of Education and Training Expense: Manufacturing vs. Nonmanufacturing

\begin{tabular}{|c|c|c|c|c|c|c|c|c|}
\hline \multicolumn{9}{|c|}{ (A) Equation: $E_{4+1}=\gamma_{0}+\gamma_{1}+E B E R_{4}+\gamma_{2} E R_{4}+c_{4}+1$} \\
\hline Group & Number & \multicolumn{3}{|c|}{ Variables } & Coefficients & t value & $\operatorname{Adj} \mathrm{R}^{2}$ & F-value \\
\hline \multirow{3}{*}{ Manufacturing } & \multirow{3}{*}{3,130} & \multicolumn{3}{|c|}{$\operatorname{Intercept}\left(\gamma_{0}\right)$} & 0.03205 & $20.53 * *$ & \multirow{3}{*}{0.0018} & \multirow{3}{*}{3.80} \\
\hline & & \multicolumn{3}{|c|}{$\operatorname{EBHR}_{\mathrm{t}}\left(\gamma_{1}\right)$} & 0.00561 & 0.93 & & \\
\hline & & \multicolumn{3}{|c|}{$\operatorname{HR}_{\mathrm{t}}\left(\gamma_{2}\right)$} & -0.10492 & $-2.41 *$ & & \\
\hline \multirow{3}{*}{ Nonmanufacturing } & \multirow{3}{*}{1,393} & \multicolumn{3}{|c|}{$\operatorname{Intercept}\left(\gamma_{0}\right)$} & 0.03567 & $27.32 * *$ & \multirow{3}{*}{0.3126} & \multirow{3}{*}{292.68} \\
\hline & & \multicolumn{3}{|c|}{$\operatorname{EBHR}_{\mathrm{t}}\left(\gamma_{1}\right)$} & 0.23748 & $24.19 * *$ & & \\
\hline & & \multicolumn{3}{|c|}{$\operatorname{HR}_{\mathrm{t}}\left(\gamma_{2}\right)$} & -0.06648 & -0.19 & & \\
\hline \multicolumn{9}{|c|}{ 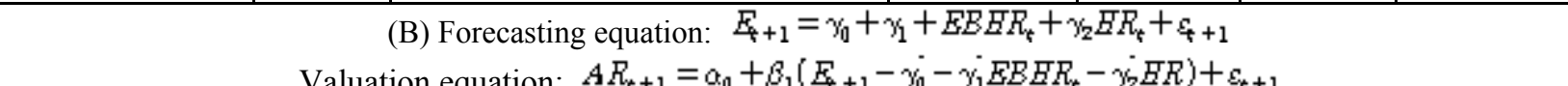 } \\
\hline Group & Number & $\gamma_{1}$ & $\gamma^{*}$ & $\gamma_{2}$ & $\gamma^{*}$ & $\begin{array}{l}\text { Test of } \\
\text { market } \\
\text { efficiency }\end{array}$ & $\begin{array}{l}\text { Likelihood } \\
\text { ratio } \\
\text { statistic }\end{array}$ & $\begin{array}{c}\text { Marginal } \\
\text { significance } \\
\text { level }\end{array}$ \\
\hline \multirow{2}{*}{ Manufacturing } & \multirow{2}{*}{3,130} & \multirow{2}{*}{0.005607} & \multirow{2}{*}{0.01508} & \multirow{2}{*}{$-0.10492 *$} & \multirow{2}{*}{0.111622} & $\gamma_{1}=\gamma^{*}{ }_{1}$ & 0.02 & 0.9020 \\
\hline & & & & & & $\gamma_{2}=\gamma_{2}^{*}$ & 0.15 & 0.6953 \\
\hline \multirow{2}{*}{ Nonmanufacturing } & \multirow{2}{*}{1,393} & \multirow{2}{*}{$0.23748 * *$} & \multirow{2}{*}{-0.00631} & \multirow{2}{*}{-0.06648} & \multirow{2}{*}{1.034736} & $\gamma_{1}=\gamma^{*}$ & 10.52 & 0.0012 \\
\hline & & & & & & $\gamma_{2}=\gamma_{2}$ & 0.18 & 0.6755 \\
\hline
\end{tabular}

Variable definitions: Refer to $<$ Table $2>, *(* *)$ : Significant at the $.05(.01)$ level.

Table 7. Market Response of Education and Training Expense: High Technology vs. Low Technology

\begin{tabular}{|c|c|c|c|c|c|c|c|c|}
\hline \multicolumn{9}{|c|}{ (A) Equation: $E_{4}+1=\gamma_{0}+\gamma_{1}+E B E R_{4}+\gamma_{2} E R_{4}+c_{4}+1$} \\
\hline Group & Number & \multicolumn{3}{|c|}{ Variables } & Coefficients & $\mathrm{t}$ value & $\operatorname{Adj} \mathrm{R}^{2}$ & F-value \\
\hline \multirow{3}{*}{ High Technology } & \multirow{3}{*}{1,675} & \multicolumn{3}{|c|}{$\operatorname{Intercept}\left(\gamma_{0}\right)$} & 0.03012 & $12.11 * *$ & \multirow{3}{*}{0.0033} & \multirow{3}{*}{3.72} \\
\hline & & \multicolumn{3}{|c|}{$\operatorname{EBHR}_{\mathrm{t}}\left(\gamma_{1}\right)$} & -0.01565 & $-2.16^{*}$ & & \\
\hline & & \multicolumn{3}{|c|}{$\operatorname{HR}_{\mathrm{t}}\left(\gamma_{2}\right)$} & -0.10482 & $-1.99 *$ & & \\
\hline \multirow{3}{*}{ Low Technology } & \multirow{3}{*}{2,848} & \multicolumn{3}{|c|}{$\operatorname{Intercept}\left(\gamma_{0}\right)$} & 0.02982 & $32.83 * *$ & \multirow{3}{*}{0.2983} & \multirow{3}{*}{556.39} \\
\hline & & \multicolumn{3}{|c|}{$\operatorname{EBHR}_{t}\left(\gamma_{1}\right)$} & 0.27273 & $33.22 * *$ & & \\
\hline & & \multicolumn{3}{|c|}{$\operatorname{HR}_{\mathrm{t}}\left(\gamma_{2}\right)$} & 0.03396 & 0.39 & & \\
\hline \multicolumn{9}{|c|}{ 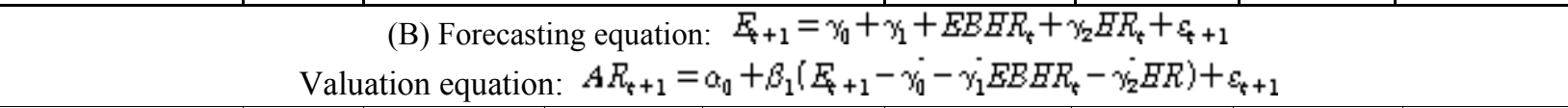 } \\
\hline Group & Number & $\gamma_{1}$ & $\gamma^{*}{ }_{1}$ & $\gamma_{2}$ & $\gamma_{2}^{*}$ & $\begin{array}{l}\text { Test of } \\
\text { market } \\
\text { efficiency }\end{array}$ & $\begin{array}{l}\text { Likelihood } \\
\text { ratio } \\
\text { statistic }\end{array}$ & $\begin{array}{l}\text { Marginal } \\
\text { significance } \\
\text { level }\end{array}$ \\
\hline \multirow{2}{*}{ High Technology } & \multirow{2}{*}{1,675} & \multirow{2}{*}{$-0.01565 *$} & \multirow{2}{*}{-0.05178} & \multirow{2}{*}{$-0.10481 *$} & \multirow{2}{*}{0.430193} & $\gamma_{1}=\gamma^{*}{ }_{1}$ & 0.72 & 0.3958 \\
\hline & & & & & & $\gamma_{2}=\gamma^{*}{ }_{2}$ & 2.98 & 0.0845 \\
\hline \multirow{2}{*}{ Low Technology } & \multirow{2}{*}{2,848} & \multirow{2}{*}{$0.272726^{* *}$} & \multirow{2}{*}{0.069836} & \multirow{2}{*}{0.033958} & \multirow{2}{*}{$-5.39625^{*}$} & $\gamma_{1}=\gamma^{*}$ & 1.74 & 0.1878 \\
\hline & & & & & & $\gamma_{2}=\gamma_{2}^{*}$ & 11.14 & 0.0008 \\
\hline
\end{tabular}

Variable definitions: Refer to $<$ Table $2>, *(* *)$ : Significant at the $.05(.01)$ level. 
Table 8. Market Response of Education and Training Expense: High Education and Training Expense vs. Low Education and Training Expense

\begin{tabular}{|c|c|c|c|c|c|c|c|c|}
\hline \multicolumn{9}{|c|}{ (A) Equation: $E_{4+1}=\gamma_{0}+\gamma_{1}+E E B R_{t}+\gamma_{2} E R_{t}+\varsigma_{\uparrow+1}$} \\
\hline Group & Number & \multicolumn{3}{|c|}{ Variables } & Coefficients & t value & $\operatorname{Adj} R^{2}$ & F-value \\
\hline \multirow{3}{*}{$\begin{array}{l}\text { High Education } \\
\text { and Training } \\
\text { Expense }\end{array}$} & \multirow{3}{*}{2,262} & \multicolumn{3}{|c|}{$\operatorname{Intercept}\left(\gamma_{0}\right)$} & 0.02479 & $12.90^{* *}$ & \multirow{3}{*}{0.1067} & \multirow{3}{*}{134.25} \\
\hline & & \multicolumn{3}{|c|}{$\operatorname{EBHR}_{t}\left(\gamma_{1}\right)$} & 0.19616 & $16.21 * *$ & & \\
\hline & & \multicolumn{3}{|c|}{$\operatorname{HR}_{\mathrm{t}}\left(\gamma_{2}\right)$} & 0.11912 & $2.56^{*}$ & & \\
\hline \multirow{3}{*}{$\begin{array}{l}\text { Low Education } \\
\text { and Training } \\
\text { Expense }\end{array}$} & \multirow{3}{*}{2,261} & \multicolumn{3}{|c|}{$\operatorname{Intercept}\left(\gamma_{0}\right)$} & 0.03662 & $20.41 * *$ & \multirow{3}{*}{0.0869} & \multirow{3}{*}{105.37} \\
\hline & & \multicolumn{3}{|c|}{$\operatorname{EBHR}_{\mathrm{t}}\left(\gamma_{1}\right)$} & 0.17989 & $14.32 * *$ & & \\
\hline & & \multicolumn{3}{|c|}{$\operatorname{HR}_{\mathrm{t}}\left(\gamma_{2}\right)$} & -72.82029 & $-2.58 * *$ & & \\
\hline \multicolumn{9}{|c|}{ 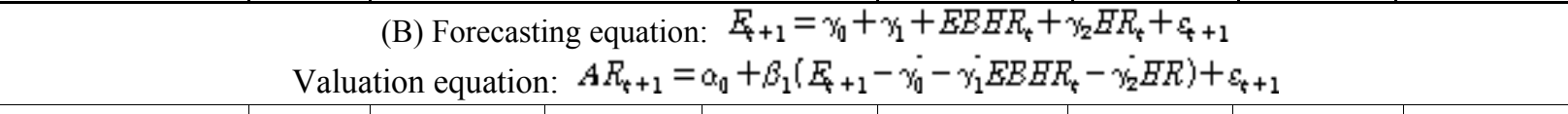 } \\
\hline Group & Number & $\gamma_{1}$ & $\gamma^{*}{ }_{1}$ & $\gamma_{2}$ & $\gamma^{*}{ }_{2}$ & $\begin{array}{l}\text { Test of } \\
\text { market } \\
\text { efficiency }\end{array}$ & $\begin{array}{l}\text { Likelihood } \\
\text { ratio } \\
\text { statistic }\end{array}$ & $\begin{array}{l}\text { Marginal } \\
\text { significance } \\
\text { level }\end{array}$ \\
\hline \multirow{2}{*}{$\begin{array}{l}\text { High Education } \\
\text { and Training } \\
\text { Expense }\end{array}$} & \multirow[b]{2}{*}{2,262} & \multirow[b]{2}{*}{$0.195742 * *$} & \multirow[b]{2}{*}{-0.09378} & \multirow[b]{2}{*}{$0.118863^{*}$} & \multirow[b]{2}{*}{0.141524} & $\gamma_{1}=\gamma^{*}{ }_{1}$ & 1.35 & 0.2461 \\
\hline & & & & & & $\gamma_{2}=\gamma_{2}^{*}$ & 0.00 & 1.0000 \\
\hline \multirow{2}{*}{$\begin{array}{l}\text { Low Education } \\
\text { and Training } \\
\text { Expense }\end{array}$} & \multirow[b]{2}{*}{2,261} & \multirow[b]{2}{*}{0.000956} & \multirow[b]{2}{*}{-0.23534} & \multirow[b]{2}{*}{$-72.8032 * *$} & \multirow[b]{2}{*}{-222.341} & $\gamma_{1}=\gamma^{*}{ }_{1}$ & 6.47 & 0.0110 \\
\hline & & & & & & $\gamma_{2}=\gamma_{2}^{*}$ & 0.90 & 0.3429 \\
\hline
\end{tabular}

Variable definitions: Refer to <Table $2>,{ }^{*}(*)$ : Significant at the $.05(.01)$ level. 
Table 9. Market Response of Education and Training Expense: Quantile (4 division)

\begin{tabular}{|c|c|c|c|c|c|c|c|c|}
\hline \multicolumn{9}{|c|}{ (A) Equation: $E_{\uparrow+1}=\gamma_{1}+\gamma_{1}+E B E R_{4}+\gamma_{2} E R_{r}+c_{4+1}$} \\
\hline Group & Number & \multicolumn{3}{|c|}{ Variables } & Coefficients & t value & $\operatorname{Adj} \mathrm{R}^{2}$ & F-value \\
\hline \multirow{3}{*}{$1^{\text {st }}$ Quantile } & \multirow{3}{*}{1,132} & \multicolumn{3}{|c|}{ Intercept $\left(\gamma_{0}\right)$} & 0.02392 & $7.34 * *$ & \multirow{3}{*}{0.0800} & \multirow{3}{*}{49.58} \\
\hline & & \multicolumn{3}{|c|}{$\operatorname{EBHR}_{\mathrm{t}}\left(\gamma_{1}\right)$} & 0.19528 & $9.78 * *$ & & \\
\hline & & \multicolumn{3}{|c|}{$\operatorname{HR}_{\mathrm{t}}\left(\gamma_{2}\right)$} & 0.12394 & $2.13^{*}$ & & \\
\hline \multirow{3}{*}{$2^{\text {nd }}$ Quantile } & \multirow{3}{*}{1,130} & \multicolumn{3}{|c|}{$\operatorname{Intercept}\left(\gamma_{0}\right)$} & 0.02899 & $9.28 * *$ & \multirow{3}{*}{0.3518} & \multirow{3}{*}{274.77} \\
\hline & & \multicolumn{3}{|c|}{$\operatorname{EBHR}_{\mathrm{t}}\left(\gamma_{1}\right)$} & 0.28880 & $23.43 * *$ & & \\
\hline & & \multicolumn{3}{|c|}{$\operatorname{HR}_{\mathrm{t}}\left(\gamma_{2}\right)$} & 1.43751 & 0.20 & & \\
\hline \multirow{3}{*}{$3^{\text {rd }}$ Quantile } & \multirow{3}{*}{1,131} & \multicolumn{3}{|c|}{$\operatorname{Intercept}\left(\gamma_{0}\right)$} & 0.04716 & $9.63 * *$ & \multirow{3}{*}{0.0049} & \multirow{3}{*}{3.72} \\
\hline & & \multicolumn{3}{|c|}{$\operatorname{EBHR}_{\mathrm{t}}\left(\gamma_{1}\right)$} & 0.02493 & 1.60 & & \\
\hline & & \multicolumn{3}{|c|}{$\operatorname{HR}_{\mathrm{t}}\left(\gamma_{2}\right)$} & -122.35146 & $-2.18^{*}$ & & \\
\hline \multirow{3}{*}{$4^{\text {th }}$ Quantile } & \multirow{3}{*}{1,130} & \multicolumn{3}{|c|}{$\operatorname{Intercept}\left(\gamma_{0}\right)$} & 0.02520 & $15.39 * *$ & \multirow{3}{*}{0.4434} & \multirow{3}{*}{414.87} \\
\hline & & \multicolumn{3}{|c|}{$\operatorname{EBHR}_{\mathrm{t}}\left(\gamma_{1}\right)$} & 0.51015 & $28.72 * *$ & & \\
\hline & & \multicolumn{3}{|c|}{$\operatorname{HR}_{t}\left(\gamma_{2}\right)$} & -521.98487 & $-2.74 * *$ & & \\
\hline \multicolumn{9}{|c|}{ 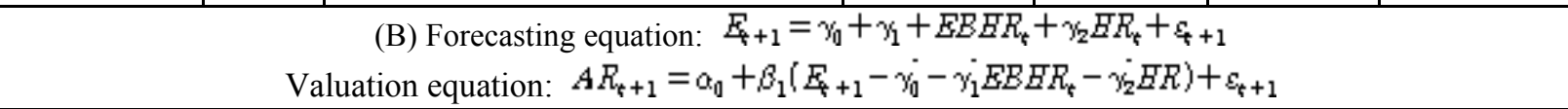 } \\
\hline Group & Number & $\gamma_{1}$ & $\gamma^{*}{ }_{1}$ & $\gamma_{2}$ & $\gamma^{*}{ }_{2}$ & $\begin{array}{l}\text { Test of } \\
\text { market } \\
\text { efficiency }\end{array}$ & $\begin{array}{l}\text { Likelihood } \\
\text { ratio } \\
\text { statistic }\end{array}$ & $\begin{array}{l}\text { Marginal } \\
\text { significance } \\
\text { level }\end{array}$ \\
\hline \multirow{2}{*}{$1^{\text {st }}$ Quantile } & \multirow{2}{*}{1,132} & $0105034 * *$ & 0111320 & 0 12378* & 0001350 & $\gamma_{1}=\gamma^{*}{ }_{1}$ & 0.01 & 0.9207 \\
\hline & & 0.190004 & 0.1111030 & 0.12570 & (20) & $\gamma_{2}=\gamma^{*}{ }_{2}$ & 0.10 & 0.7485 \\
\hline $2^{\text {nd }}$ Ouantile & 1130 & $0288723 * *$ & 000103 & 1427142 & 106075 & $\gamma_{1}=\gamma^{*}{ }_{1}$ & 6.89 & 0.0087 \\
\hline 2 Quantile & 1,100 & $0.200 / 25$ & 0.00103 & $1.43 / 142$ & $-10.00 / 2$ & $\gamma_{2}=\gamma^{*}{ }_{2}$ & 0.04 & 0.8500 \\
\hline $3^{\text {rd }}$ Ountile & 1131 & 0024025 & $0262 * *$ & $122251 *$ & 1241082 & $\gamma_{1}=\gamma^{*}{ }_{1}$ & 13.13 & 0.0003 \\
\hline & & 0.024925 & -0.5050 & -122.501 & 124.1903 & $\gamma_{2}=\gamma^{*}{ }_{2}$ & 0.41 & 0.5230 \\
\hline $4^{\text {th }}$ Ouantile & 1130 & $0509866 * *$ & -008421 & $-52160 * *$ & 208326 & $\gamma_{1}=\gamma^{*}{ }_{1}$ & 11.20 & 0.0008 \\
\hline 4 Quamtire & 1,150 & & -0.00421 & -521.09 & -2005.20 & $\gamma_{2}=\gamma^{*}{ }_{2}$ & 0.67 & 0.4136 \\
\hline
\end{tabular}

Variable definitions: Refer to <Table 2>,* (**): Significant at the $.05(.01)$ level. 